\title{
Genetic Change from Colorectal Carcinoma Patients Using Comparative Genomic Hybridization
}

\author{
Jae Sik Lee
}

Department of Clinical Laboratory Science, Hyejeon College, Hongseong 32244, Korea

\section{비교유전자교잡법을 이용한 대장암환자에서의 유전자변화}

\author{
이재식
}

혜전대학교 임상병리과

\begin{abstract}
Colorectal carcinoma is one of the four major cancers in Korea, and it shows the tendency of increase every year due to economic development and changes to western styles. Accordingly, various diagnostic methods are needed and so comparative genomic hybridization (CGH) was performed. Deletion was detected on $5 q(10 \%), 10 q(17 \%), 17 p(40 \%), 18 p(23 \%), 18 q(47 \%), 22 q$ (23\%), and higher deletion loci were 18q (12/30, 47\%), 17p (12/30, 40\%), and 22q (7/30, 23\%). Amplification was shown on chromosomes 6pq (10\%), 7p (17\%), 7q (33\%), 8q (13\%), 9pq (10\%), $12 q(17 \%), 13 q(37 \%), 20 p(23 \%)$, and 20q (57\%) respectively. The highest amplification was detected on chromosomes 20q (17/30, 57\%), 13q (11/30, 37\%), and 7q (10/30, 33\%). The genetic change pattern with the locus of colorectal carcinoma was shown mean 3.1 (amplification 1.7, deletion 1.4) on the right colorectal carcinoma, while rectal carcinoma appeared high mean 6.3 (amplification 3.7, deletion 2.6) $(p<0.001)$. The genetic change pattern with lymphatic gland metastasis, mean 3.5 (amplification 2.2, deletion 1.3) from "no metastasis" group, while high mean 6.3 (amplification 3.5, deletion 2.8) from metastasis group ( $p<0.003)$. The genetic change pattern with disease stages appeared mean 3.5 (amplification 2.1, deletion 1.4) from I-II stages, while high mean 6.0 (amplification 3.4, deletion 2.6) from III-IV stages $(p<0.006)$. No significance was observed in comparing histological classification and serum CEA increased groups.
\end{abstract}

Keywords: Amplification, Colorectal carcinoma, Comparative genomic hybridization (CGH), Deletion

This is an Open Access article distributed under the terms of the Creative Commons Attribution Non-Commercial License (http://creativecommons.org/licenses/by-nc/4.0) which permits unrestricted non-commercial use, distribution, and reproduction in any medium, provided the original work is properly cited.

Copyright () 2015 The Korean Society for Clinical Laboratory Science. All rights reserved.
Corresponding author: Jae Sik Lee

Department of Clinical Laboratory Science, Hyejeon College, Hongseong 32244, Korea Tel: 82-41-630-5340

E-mail: jslee@hanmail.net

Received: September 29, 2015

Revised: October 21, 2015

Accepted: November 1, 2015

\section{Introduction}

Colorectal carcinoma is one of four major cancers in Korea and it shows the tendency of increase every year due to changed western style from economic development (Shin et al., 2013). The mortality of colorectal carcinoma came second in the United States. Colorectal carcinom is also commonly known as the malignant tumor diagnosed in Western countries (Provenzale et al., 2015).
According to statistics, South Koreans shows higher increase in incidence and mortality of colorectal carcinoma last 24 years. As the fourth by cancer, there is much growing every year since 1999 (National Statistical Office of Korea, 1990 2013).

In general, there are environmental such as dietary life and genetic factors as an important factor of colorectal carcinoma. The molecular and biological changes have been known changes caused by a gradual genetic changes between cancer 
gene and cancer suppression gene (Henrikson et al., 2015). It was known that cancer occurs as a result of which cancer gene is activated or cancer suppression gene is inactivated, carrying lose balance between activation and inactivation (O'Mahoney et al., 2015).

As research method to find the cause of colorectal carcinoma, comparative genomic hybridization (CGH) to know the changes to the entire chromosomes is being used.

This technique is to find the changes of DNA copy number from tumor gene which is convenient method to know the genetic variation of tumor genome gene and now is being applied in the gene change research of solid tumors (Sawada et al., 2013).

So far, it has been reported that the colorectal carcinoma-linked gene are $K$-ras, $c$-met, $c$-src for carcinogenic gene and $D C C, A P C, p 53$ for tumor suppression gene. Especially, DCC gene is known for closely related to prognosis. (Laczmanska et al., 2014). It was reported that there are amplification of chromosomes 7, 13 and deletion of chromosomes 17, 18 due to difficult specimen dealing and hard cell culture on cytogenetical research with few chromosome test (Brim et al., 2012).

The author investigated the whole genetic change from Korean colorectal carcinoma using CGH and tried to figure out a pivotal gene for carcinogenesis mechanism of colorectal carcinoma, treatment and beneficial prognosis decision.

\section{Materials and Methods}

\section{Materials}

Tissues of colorectal carcinoma from 30 patients who was operated in $\mathrm{K}$ hospital in Busan, to analyze comparative genomic hybridization, were used. DNAs from tumor tissues and normal blood samples were hybridized. Thirty patients consist of 14 males and 16 females with average aged 55 (32 80). According to American Joint Committee on Cancer (AJCC), there were two stages I, ten stage II, 15 stage III and three stage IV, respectively. From tissue's pattern, there were 17 high-differentiated types, 8 mid-differentiated types, 3 low-differentiated types and 3 mucous carcinoma, respectively (Table 1).
Table 1. Mean number of chromosomal gains, losses and total number of events per tumor in colorectal carcinoma according to the location, the level of serum CEA, histological type and stage

\begin{tabular}{lcccc}
\hline Variables & Cases & Amplification & Deletion & Total \\
\hline Location & & & & \\
Right colon & 12 & $1.7 \pm 0.98$ & $1.4 \pm 0.90$ & $3.1 \pm 1.56$ \\
Rectum & 18 & $3.7 \pm 1.74$ & $2.6 \pm 1.85$ & $6.3 \pm 2.67$ \\
$p$-value & & 0.001 & 0.034 & 0.001 \\
Serum CEA & & & & \\
I5 (ng/mL) & 16 & $3.1 \pm 2.14$ & $2.1 \pm 1.84$ & $5.2 \pm 3.26$ \\
>5 (ng/mL) & 14 & $2.7 \pm 1.33$ & $2.1 \pm 1.41$ & $4.8 \pm 2.18$ \\
$p$-value & & 0.603 & 0.895 & 0.797 \\
Differentiation & & & & \\
Well & 17 & $2.5 \pm 1.46$ & $2.0 \pm 1.80$ & $4.5 \pm 2.74$ \\
Moderate to & 13 & $3.4 \pm 2.10$ & $2.2 \pm 1.42$ & $5.6 \pm 2.79$ \\
poor & & & & \\
$p$-value & & 0.199 & 0.707 & 0.295 \\
Lymph node & & & & \\
Negative & 14 & $2.2 \pm 1.25$ & $1.3 \pm 0.91$ & $3.5 \pm 1.56$ \\
N1-3 & 16 & $3.5 \pm 2.00$ & $2.8 \pm 1.80$ & $6.3 \pm 2.96$ \\
$p$-value & & 0.047 & 0.007 & 0.003 \\
Stage & & & & \\
I II & 12 & $2.1 \pm 1.00$ & $1.4 \pm 0.90$ & $3.5 \pm 1.57$ \\
III IV & 18 & $3.4 \pm 2.01$ & $2.6 \pm 1.85$ & $6.0 \pm 2.97$ \\
$p$-value & & 0.039 & 0.034 & 0.006 \\
Total & 30 & $2.9 \pm 1.60$ & $2.1 \pm 1.47$ & $5.0 \pm 2.43$ \\
\hline
\end{tabular}

\section{Method}

1) DNA preparation and labeling

DNA was extracted from tumor tissue using a genomic DNA purification kit (Promega, USA), and from normal male blood using DNAzol genomic DNA isolation reagent (Molecular research center inc, USA), respectively. Genomic DNA of normal blood, used as a reference DNA was labeled with digoxigenin-11-dUTP with nick translation kit (Boeringer Manheim, Germany). The size of the probe was adjusted to 500 2000 bp on the concentration of DNAse I during the labeling process. Digoxigenin-labeled reference DNA and biotin-labeled tumor DNA were precipitated with ethanol and $20 \mu \mathrm{g}$ of cot-1 DNA (Boehringer Mannheim, Germany).

\section{2) Preparation of the metaphase chromosome \\ Lymphocytes from normal male blood were obtained by phytohemagglutin stimulation and subsequently cultured for 3 days. Slides were prepared by a conventional method. For 4',6-diamidino-2-phenylindole (DAPI) analysis, samples were stored at $65^{\circ} \mathrm{C}$ overnight and placed at $-20^{\circ} \mathrm{C}$ and then used.}




\section{3) Hybridization}

The CGH method was used with a slight modification of Kallioniemi. The probe was prepared with 200 500 ng of labeled-normal DNA and labeled-tumor DNA, respectively. After mixing well, sodium acetate (1/10 volume), 2.5 times ethanol, $10 \mu \mathrm{L}$ Cot-1 DNA, were added and incubated for 2 3 hours at $70^{\circ} \mathrm{C}$. The supernatant was removed after centrifugation at $14,000 \mathrm{~g}$ for $30 \mathrm{~min}$ and the pellets were diluted with $10 \mu \mathrm{L}$ of a hybrid mixture (50\% formamide, $10 \%$ dextran sulfate/2X SSC, $\mathrm{pH}$ 7.0). The diluted pellets were denatured at $73^{\circ} \mathrm{C}$ and, then used. Prepared metaphase chromosomes from the above were denatured at $73^{\circ} \mathrm{C}$ for 2 min and, then hybridized for $2 \sim 3$ days.

\section{4) Washing and counterstaining}

Prepared samples were washed three times with 50\% formamide at $45^{\circ} \mathrm{C}$ for $7 \mathrm{~min}$, and subsequently washed a further two times with $2 \mathrm{X} \mathrm{SSC}$ at $45^{\circ} \mathrm{C}$ for $7 \mathrm{~min}$. A final wash in 2X SSC at room temperature was followed by a 5 min-preblocking with a preblocking solution (1\% BSA in 2X SSC). Biotinylated DNA was stained with $5 \mu \mathrm{g} / \mathrm{mL}$ of fluorescein isothiocyanate (FITC) conjugated with avidin and digoxigenin-labeled DNA with $1 \mu \mathrm{g} / \mathrm{mL}$ of antidigoxigenin rhodamine, respectively and then counterstained with DAPI.

\section{5) Image analysis}

Hybridized slides were analyzed by an image analyzer, Cytovision system (Applied Image, UK). A fluorescence microscope with an attached triple band pass splitter and emission filter was used. A program for CGH, supplied by Applied Image Co. analysis was also purchased and used. The ratio of the profile was calculated with the fluorescenced ratio between FITC and rhodamine on each chromosome and karyotyping analysis was performed using DAPI-stained chromosomes.

Chromosomal regions where the FITC to rhodamine exceeded 1.15 were considered amplification, while those below 0.85 were considered deletion. DNA from normal lymphocytes was labeled with different flourochromes and the value was chosen as the cut-off level after the evaluation of five metaphase-stage cells. Single chromatid or one of two chromosomes showing specific signal-amplification were excluded, considering a non-specific reaction. Telomeric and heterochromatic regions were also excluded from the analysis. A fluorescenced ratio exceeding 1.5 means high-level amplification. The mean value was calculated with analysis of at least four chromosomes.

\section{Statistical analysis}

The correlation between the number of genetic alterations, location of colorectal carcinoma, histological differention chart, metastatis of lymph node, disease stage, and the increase of serum CEA were compared by Comparative Genomic Hybridization. These correlations were verified by the $\mathrm{X}$-square test using the SPSSWIN (ver 10.0) program and were considered significant when the $p$-value was less than 0.05 .

\section{Results}

\section{Resutls of amplification}

Amplification was shown on chromosomes 6pq (10\%), 7p (17\%), 7q (33\%), 8q (13\%), 9pq (10\%), 12q (17\%), 13q (37\%), 20p (23\%), 20q (57\%), respectively. The highest amplification was detected on chromosomes 20q (17/30, 57\%), 13q (11/30, $37 \%)$ and $7 q(10 / 30,33 \%)$ (Fig. 1).

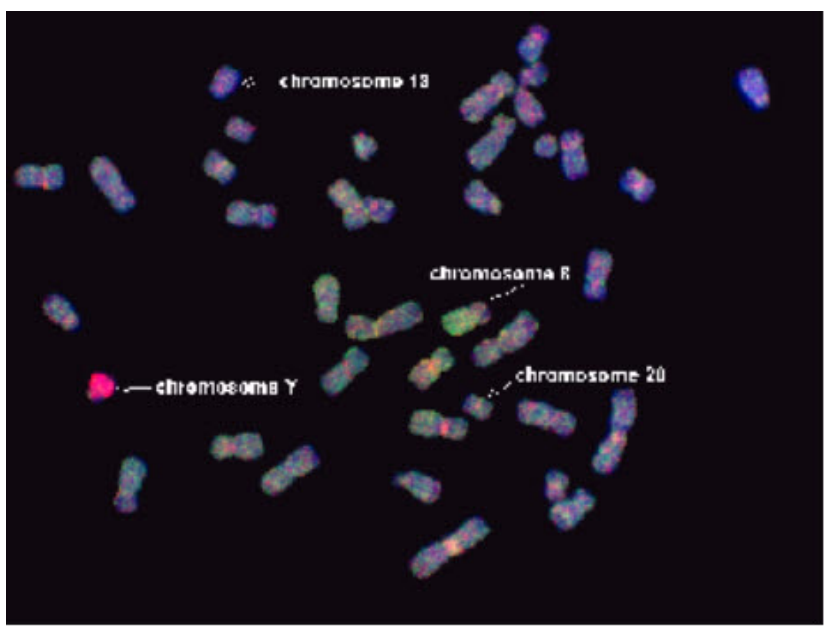

Fig. 1. An example of a digital image from a comparative genomic hybridization experiment. Chromosomal regions that were over represented (amplified) in the tumor were visualized as a predominantly green color, whereas regions that were lost (deleted) from the tumor were seen as region with a predominantly red color $(\times 1,000)$ 


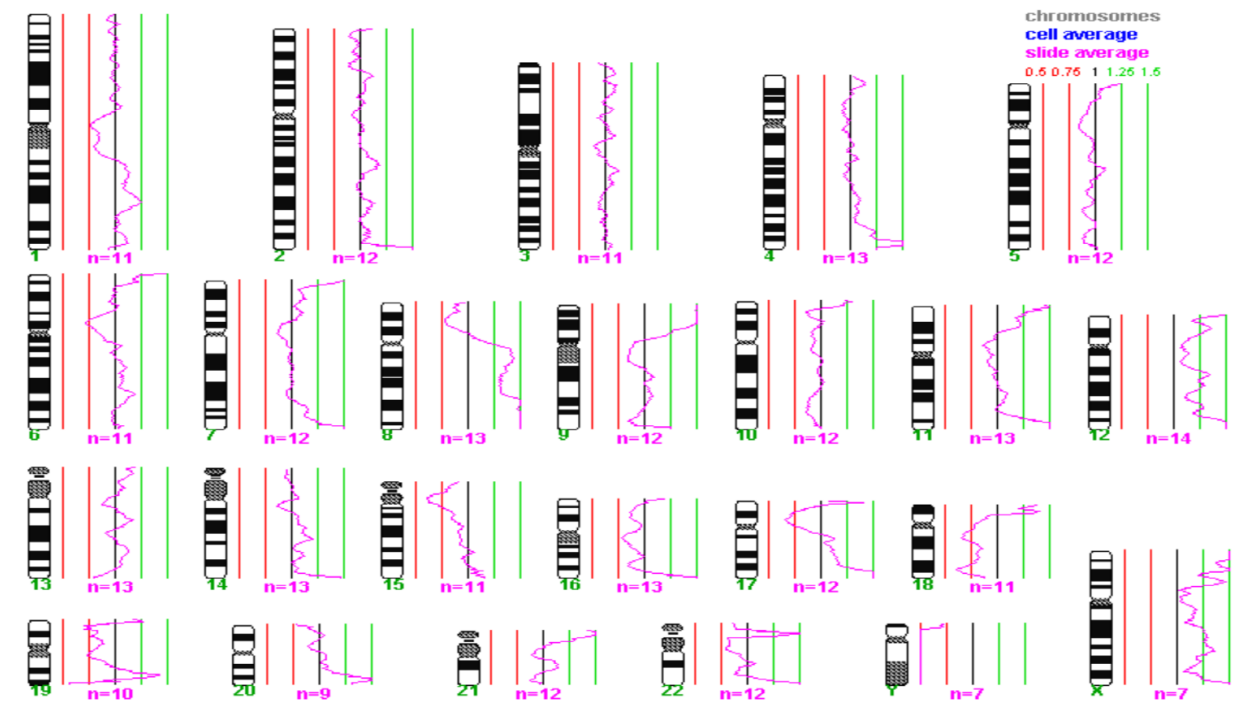

Fig. 2. An example of an average ratio profile for a colorectal carcinoma. The three vertical lines on the right side of the ideograms reflect different values of the fluorescence ratio between the tumor and the normal DNA. The values are $0.75,1.0$, and 1.25 from left to right. The ratio profile (curve) was computed as a mean value of ten metaphase spreads.

\section{Results of deletion}

Deletion was observed on 5q (10\%), 10q (17\%), 17p (40\%), $18 \mathrm{p}(23 \%), 18 \mathrm{q}(47 \%), 22 \mathrm{q}(23 \%)$ and higher deletion loci were 18q (12/30, 47\%), 17p (12/30, 40\%) and 22q (7/30, 23\%) (Fig. 2).

\section{Location of colrectal carcinoma, lymphatic gland metastasis, histological classification, serum CEA difference}

The genetic change pattern with the locus of colorectal carcinoma was shown mean 3.1 (amplification 1.7, deletion 1.4) on the right colorectal carcinoma, while rectal carcinoma appeared high mean 6.3 (amplification 3.7, deletion 2.6) $(p<0.001)$. The genetic change pattern with lymphatic gland metastasis, mean 3.5 (amplification 2.2, deletion 1.3) from "no metastasis" group, while high mean 6.3 (amplification 3.5, deletion 2.8) from metastasis group $(p<0.003)$.

The genetic change pattern with disease stages was appeared mean 3.5 (amplification 2.1, deletion 1.4) from I II stages, while high mean 6.0 (amplification 3.4, deletion 2.6) from III IV stages $(p<0.006)$. No big difference was shown between comparison with histological classification and serum CEA increased group.

\section{Discussion}

The colorectal carcinoma mortality of Koreans is increa- sing from 4.5 (per 100,000 persons) in 1990 to 16.4 (per 100,000), showing abrupt rise 3.64 times dramatically. That of malignant neoplasm with organs' location is showing $10.8 \%$ and stomach cancer, one of top three cancers, is growing nearly 12\% (National Statistical Office of Korea, 1990 2013).

Due to westernized diet like US and western European countries, colorectal carcinoma is expected a rapid increase. Therefore, a number of research at home and abroad has been tried to find the occurrence and progress of colorectal carcinoma (Provenzale et al., 2015).

The principle of comparative genomic hybridization (CGH) is that DNA extracts from tumor tissue and normal tissue are labeled with different fluorescent and hybridized with metaphase chromosomes and evaluated by the changes of DNA copy number with the ratio of competitive-combined fluorescence sensitivity. (Shi et al., 2012).

The results obtained through GCH method indicated compared in this experiment as the ratio of amplification to deletion was $1.33: 1$, which is relatively near to average value of 1:1 to 2.7:1 from various foreign reports (Nakao et al., 2001).

The colorectal carcinoma is relatively well known the outbreak process of cancer by genetic factors. According to Vogelstein's multilevel outbreak model, the normal epithelium change hyperplastic epithelium by $A P C$ gene into early adenoma on chromosome $5 q$ variation or deletion. Subse- 
quently, it developed into mid-stage adenoma by ras gene from DNA hypomethylation and chromosome 18q variation and finally progressed into late adenoma by $D C C$ gene on chromosome 18q deletion. It was reported experimentally that late adenoma developed into cancer by chromosome 17 deletion on $p 53$ damage and metastasis was undertaken by other genes (Vogelstein et al., 1990).

The most valuable point in this study is $7 \mathrm{q}$ amplification which showed different features with cancer stages. Early stage of cancer showed 7cen-q11.2 amplification and 7q21.1-35 amplification appeared on metastasis (Zenklusen et al., 1995). The $c$-met as a early cancer gene on 7q loci was played a pivotal role in all cancers and appeared frequently from early breast and prostate cancer. 7q amplification is typically present in colon cancer as well as colon adenoma (Ried et al., 1996).

The detectable ratio of 7q amplification from CGH of this study totally $33 \%$ but was abruptly increased at disease stage III IV by $60 \%$ compared with stages I and II by $10 \%$. Specific amplification on 7q chromosome from 2 out of 3 samples was found. The 7q amplification was reported from $22 \%$ to $48 \%$, which was corresponded with that (33\%) of this study (Paredes-Zaglul et al., 1998; Brim et al., 2014).

These results correspond with those of previous reports which mentioned 7q amplification by 71\% (Meijer et al., 1998) on metastasized samples and showed a 4-fold increase in metastasized cancer compared with that in the early stage. It is known that 7q amplifications was associated with the colorectal carcinoma progress and metastasis (Nakao et al., 2001).

Another feature is $13 \mathrm{q}$ amplification and cancer genes related with $13 \mathrm{q}$ loci are $B R C A 2$ of $13 \mathrm{q} 12, R B 1$ of $13 \mathrm{q} 21$ and $D P 1$ of $13 \mathrm{q} 34$. DP1 gene activated by D1 cyclin and CDK during G1 to S1 stage of cell cycling, which plays a crucial role for transcription of several genes (Day et al., 2013).

It is especially reported that this $D P 1$ gene was amplified in the squamous epithelium cancer of esophagus. FLT1 as another possible gene is considered but there was no confident proof for this existence. However, it is considered that this FLT1 plays a role in normal or abnormal development of angiogenesis (Gerber et al., 1997).

Previous reports showed that 13q amplification increased more than four fold and a more than two to three fold increase in metastasized cancer than in early cancer stages (Paredes-Zaglul et al., 1998). This study showed results of CGH 100\% detection in metastasized liver cancer compared with total detection ration of $37 \%$.

20q amplification was frequently found in colorectal carcinoma as well as in stomach, pancreas, mammary, urinary bladder cancer, respectively. The frequency of amplification shows a 2.5-fold increase and has played a crucial role when intestinal adenoma develops into cancer (Therkildsen et al., 2013).

This locus, chromosome 20q12, includes lots of genes such as E2F1 gene and $A 1 B 1$, which activates cell cycles on G1 to $S$ stage and boosts estrogen transcription, respectively. BTAK/STK15 gene on chromosome 20q13 produces serine-threonin kinase which is associated with centromere cloning on breast cancer, ovary, prostate and neurocytoma. NABC14 gene on 20q13.2 was involved in development of colon adenoma to colorectal carcinoma which is well known as a high-potent carcinogenic gene on the development of breast cancer. This can be suggested that this locus can have a proto-oncogene function.

It was also reported that 20q amplification so markedly appeared that metastasis of colorectal carcinoma may be elevated when $c$-SrC gene activated (Arriba et al., 2015). In this study, CGH (67\%) were markedly detected in the metastasized liver cancer compared with the total detection frequency (57\%). This means that the detection rate was high $(94 \%)$ in metastasized liver cancer compared with an early cancer stage (26\%) (Nakao K et al., 2001). It is estimated that amplification on 7q, 13q, 20q plays a primary role in the early to metastasized liver cancer stages.

Chromosome 17 p deletion was shown in $40 \%$ of $\mathrm{CGH}$ which can be explained by $p 53$ gene deletion. The results from this study was found with similar frequency from previous reports. Point mutation of $p 53$ and allelic deletion showed the high frequency in colorectal carcinoma, which plays an important function in the development and progression of colorectal carcinoma, reported in the previous reports (Brim et al., 2014).

p53 inhibits cell division and growth, controlling gene 
transcription after combination on special loci. With cell growth inhibition mechanism, protein by $p 53$ is $21 \mathrm{KD}$-cipi or WAF1 which stimulates protein production thereby lengthens G1 stage and recovers damaged DNA. As well as colon cancer, stomach cancer, lung cancer, liver cancer include a wide range of cancer from about $50 \%$ of genetic variation. Sporadic colorectal cancer at $75 \%$ of one allele of gene deletion accompanies with by a gene mutation of the rest allele genes.

Deletion was detected the most about $47 \%$ on $18 \mathrm{q}$ for CGH, which showed similar results to previous reports (Laczmanska et al., 2014). DCC and DPC4 are existed on 18q were well known, which are related with cancer development after $D C C$ gene alternation and normal 18q heterogamy deletion. This gene was well known on colorectal carcinoma and pancreatic cancer and suggests that this gene is associated with progressive development to colorectal carcinoma based on specially appearance in the late stage of colon adenoma. Additionally, previous reports mentioned that deletion on 18q21, can be a relapsed region after treatment, showed an $82 \%$ recurrence (Watanabe et al., 2001).

Accordingly, it is proposed that it becomes the index for selection of prognosis and treatment. SMAD2 gene on 18q21 and SMAD4/DPC4 on 18q21.1 are well known for controlling of TGF- $\beta$ pathway which inhibits signals of cell growth from nucleus (Shi et al., 2012).

22q deletion showed a comparatively high detection. Previous reports said that 22q deletion discriminated between deletion and non-deletion. 22q deletion was detected the most with $26 \sim 56 \%$ in a Japanese-oriented experiment (Nakao et al., 1998) and lower with 7 8\% in other Western Europe studies (De Angelis et al., 1999).

It is possibly proposed that there can be difference in race. PCNA gene is located in 22q, which is part of DNA synthesis enzyme and plays a crucial role in DNA synthesis, repair from damaged DNA or controlling of cell cycle. It was reported that there will be higher frequency in case of bad prognosis.

It is proposed that $17 \mathrm{p}, 18 \mathrm{q}$ and $22 \mathrm{q}$ deletion is more strongly related to the occurrence and prognosis, as an index of colorectal carcinoma, than metastasis. In this study, it was found that there were reasonable differences of genetic alteration on lymph node metastatis, disease stage and location with statistical significance. These results are in accordance with that of previous reports.

In this study, CGH is one of cytogenetics applied tools to analyze results from only cultured cells, thereby to overcome difficulties of tumor cell culture and chromosome change from lots of tumor cells which can't exist in mitoic phase. CGH is also a very effective way to confirm changes of entire chromosomes with one hybridization.

Accordingly, it can be screened an altered loci of gene which is involved with colorectal development as well as to know entirely about various gene change of tumor origin and its development.

Based on CGH's strong points such as getting lots of information about entire tumor genome at once, it will be very useful to understand carcinogenesis and further development from this study.

\section{요 약}

대장암은 우리나라에서 많이 발병하는 4 대 암의 하나로써, 경제 적인 발전을 통한 생활양식의 서구화 등으로 인해 매년 증가 추세 에 있다. 따라서 대장암의 다양한 진단방법이 요구되고 있으며, 새 로운 진단방법으로 가능한 Comparative Genomic Hybridization 실험을 하였다. 실험결과 Deletion은 $5 \mathrm{q}(10 \%), 10 \mathrm{q}(17 \%), 17 \mathrm{p}$ (40\%), 18p (23\%), 18q (47\%), 22q (23\%)이며, 가장 많은 빈도로 관찰된 것은 $18 \mathrm{q}, 17 \mathrm{p}, 22 \mathrm{q}$ 로서 $18 \mathrm{q}$ 에서 $47 \%$ (14/30)가, $17 \mathrm{p}$ 에 서 40\%(12/30)가, 22q에서 23\% (7/30)가 관찰되었다. Amplification 은 염색체 6pq (10\%), 7p (17\%), 7q (33\%), 8q (13\%), 9pq (10\%), $12 \mathrm{q}(17 \%), 13 \mathrm{q}(37 \%), 20 \mathrm{p}(23 \%), 20 \mathrm{q}(57 \%)$ 부분에서 증폭이 보 여졌다. 가장 많은 빈도로 관찰된 것은 $20 \mathrm{q}, 13 \mathrm{q}, 7 \mathrm{q}$ 로서 $20 \mathrm{q}$ 에서 $57 \%$ (17/30)가, $13 \mathrm{q}$ 에서 $37 \%$ (11/30)가, $7 \mathrm{q}$ 에서 33\% (10/30)가 관찰되었다. 대장암의 위치에 따른 유전자 변이 양상은 우측 대장 암이 평균 3.1 개(증폭 1.7 개, 결실 1.4 개)인데 반해, 직장암은 평균 6.3개(증폭 3.7개, 결실 2.6개)로서 높았다 $(p<0.001)$. 림프절 전 이에 따른 유전자 변이 양상은 전이가 없는 군에서는 평균 3.5 개(증 폭 2.2개, 결실 1.3 개)인데 반해, 림프절 전이가 있는 군은 평균 6.3 개(증폭 3.5 개, 결실 2.8 개)로서 높았다 $(p<0.003)$. 병기별에 따른 유전자 변이 양상은 I II병기에서는 평균 3.5개(증폭 2.1개, 결실 1.4 개)인데 반해, III IV병기에서는 평균 6.0개(증폭 3.4개, 결실 2.6 개 $)$ 로서 높았다 $(p<0.006)$. 조직학적 분류에 따른 비교와 혈청 $\mathrm{CEA}$ 증가군에 대한 비교는 큰 차이가 없었다. 
Acknowledgements: None

Funding: None

Conflict of interest: None

\section{References}

1. Arriba M, García JL, Inglada-Pérez L, Rueda D, Osorio I, Rodríguez Y, et al. DNA copy number profiling reveals different patterns of chromosomal instability within colorectal cancer according to the age of onset. Mol Carcinog. 2015,25:e22315.

2. Brim H, Lee E, Abu-Asab MS, Chaouchi M, Razjouyan H, Namin $\mathrm{H}$, et al. Genomic aberrations in an African American colorectal cancer cohort reveals a MSI-specific profile and chromosome X amplification in male patients. PLoS One. 2012,7(8):e40392.

3. Day E, Poulogiannis G, McCaughan F, Mulholland S, Arends MJ, Ibrahim AE, et al. IRS2 is a candidate driver oncogene on $13 \mathrm{q} 34$ in colorectal cancer. Int J Exp Pathol. 2013,94(3):203-211

4. De Angelis PM, Clausen OP, Schj ø lberg A, Stokke T. Chromosomal gains and losses in primary colorectal carcinomas detected by CGH and their associations with tumour DNA ploidy, genotypes and phenotypes. Br J Cancer. 1999,80(4):526-535

5. Gerber HP, Condorelli F, Park J, Ferrara N. Differential transcriptional regulation of the two vascular endothelial growth factor receptor genes. Flt-1, but not Flk-1/KDR, is up-regulated by hypoxia. J Biol Chem. 1997,272(38):23659-23667.

6. Henrikson NB, Webber EM, Goddard KA, Scrol A, Piper M, Williams MS, et al. Family history and the natural history of colorectal cancer: systematic review. Genet Med. 2015,17(9): 702-712

7. Laczmanska I, Karpinski P, Kozlowska J, Bebenek M, Ramsey D, Sedziak T, et al. Copy number alterations of chromosomal regions enclosing protein tyrosine phosphatase receptor-like genes in colorectal cancer. Pathol Res Pract. 2014,210(12): 893-896

8. Meijer GA, Hermsen MA, Baak JP, van Diest PJ, Meuwissen SG, Beliën JA, et al. Progression from colorectal adenoma to carcinoma is associated with non-random chromosomal gains as detected by comparative genomic hybridization. J Clin Pathol. 1998,51(12):901-909.

9. Nakao K, Shibusawa M, Ishihara A, Yoshizawa H, Tsunoda A, Kusano M, et al. Genetic changes in colorectal carcinoma tumors with liver metastases analyzed by comparative genomic hybridization and DNA ploidy. Cancer. 2001,91(4):721-726.

10. Nakao K, Shibusawa M, Tsunoda A, Yoshizawa H, Murakami M, Kusano M, et al. Genetic changes in primary colorectal cancer by comparative genomic hybridization. Surg Today. 1998,28(5):
567-569.

11. O'Mahoney PR, Scherl EJ, Lee SW, Milsom JW. Adenocarcinoma of the ileal pouch mucosa: case report and literature review. Int J Colorectal Dis. 2015,30(1):11-18.

12. Paredes-Zaglul A, Kang JJ, Essig YP, Mao W, Irby R, Wloch M, et al. Analysis of colorectal cancer by comparative genomic hybridization: evidence for induction of the metastatic phenotype by loss of tumor suppressor genes. Clin Cancer Res. 1998,4(4): 879-886

13. Provenzale D, Jasperson K, Ahnen DJ, Aslanian H, Bray T, Gupta S, et al. Colorectal Cancer Screening, Version 1. 2015. J Natl Compr Canc Netw. 2015,13(8):959-968.

14. Ried T, Knutzen R, Steinbeck R, Blegen H, Schröck E, Heselmeyer $\mathrm{K}$, et al. Comparative genomic hybridization reveals a specific pattern of chromosomal gains and losses during the genesis of colorectal tumors. Genes Chromosomes Cancer. 1996,15(4):234-245.

15. Sawada T, Yamamoto E, Suzuki H, Nojima M, Maruyama R, Shioi $\mathrm{Y}$, et al. Association between genomic alterations and metastatic behavior of colorectal cancer identified by array-based comparative genomic hybridization. Genes Chromosomes Cancer. 2013,52(2): 140-149.

16. Shi ZZ, Zhang YM, Shang L, Hao JJ, Zhang TT, Wang BS, et al. Genomic profiling of rectal adenoma and carcinoma by array-based comparative genomic hybridization. BMC Med Genomics. 2012,5:52.doi:10.1186/1755-8794-5-52.

17. Shin A, Jung KW, Won YJ. Colorectal cancer mortality in Hong Kong of China, Japan, South Korea, and Singapore. World J Gastroenterol. 2013,19(7):979-983.

18. Therkildsen C, Jönsson G, Dominguez-Valentin M, Nissen A, Rambech E, Halvarsson B, et al. Gain of chromosomal region 20q and loss of 18 discriminates between Lynch syndrome and familial colorectal cancer. Eur J Cancer. 2013,49(6):1226-1235

19. Tirkkonen M, Tanner M, Karhu R, Kallioniemi A, Isola J, Kallioniemi OP. Molecular cytogenetics of primary breast cancer by CGH. Genes Chromosomes Cancer. 1998,21(3):177-184

20. Vogelstein B, Fearon ER. A genetic model for colorectal tumorigenesis. Cell. 1990,61(5):759-767.

21. Watanabe T, Wu TT, Catalano PJ, Ueki T, Satriano R, Haller DG, et al. Molecular predictors of survival after adjuvant chemotherapy for colon cancer. $N$ Engl J Med. 2001,344(16):11961206

22. Zenklusen JC, Thompson JC, Klein-Szanto AJ, Conti CJ. Frequent loss of heterozygosity in human primary squamous cell and colon carcinomas at 7q31.1: evidence for a broad range tumor suppressor gene. Cancer Res. 1995,55(6):13471350 . 